\author{
Eva Sicherl \\ Filozofska fakulteta, Ljubljana
}

\title{
The English Suffix -Wise and its Productivity from the Non-Native Speaker Perspective
}

Članek skuša osvetliti produktivno rabo angleške pripone -wise v sodobni angleščini, njene različne pomene in možne prevodne ustreznice v slovenskem jeziku. Slovenščina besedotvorno gledano ne pozna enake možnosti izpeljave za izražanje teh pomenov, zato se mora pri prevajanju zateči $\mathrm{v}$ opisne ustreznike.

The article aims to shed some light on the productive use of the suffix -wise in present-day English, its meanings, and possible equivalent paraphrases in the Slovene language, which, from the word-formational point of view, does not employ the same derivational tool to express the same meanings.

\section{Introduction}

In recent decades an increase in the use of the English suffix -wise was commented on by several authors (cf. Plag, Dalton-Puffer and Baayen 1999; Dalton-Puffer and Plag 2000; Yezbick and Closs Traugott 2005; Cowie 2006; Plag 2006). In fact, this phenomenon has also elicited comment and advice from sources following a more prescriptive tradition, such as style manuals used and prepared by editorial staff of various newspapers and magazines, discouraging language users from employing this suffix by proclaiming it non-standard. Thus, for example, The University of Minnesota Style Manual ${ }^{1}$ states firmly: "Adding the suffix -wise to a word is almost never appropriate. [...] Avoid it." Pullum and Huddleston (2002: 567) explicitly mention that the construction is frowned upon by prescriptivists, but seems to have "caught on" in less formal, particularly, spoken discourse. Indeed, the formation of adverbs in -wise from nouns is alive and well, thriving in both American and British English, as illustrated by a private letter received by the author of the present article from her English friends:

(1) Our family seems o.k., although P. is causing some concern healthwise.

\footnotetext{
${ }^{1}$ The Style Manual is available on the Internet at www1.umn.edu/urelate/style/language-usage.html (accessed February 2007), but is by no means isolated when it comes to advising against the use of -wise; cf. also englishplus.com/grammar/00000272.htm, or, for example, www.whitman. edu/president/cronin/articles/ thewritestuff.cfm?print, which states: "The suffix -wise has a place in established forms like clockwise, otherwise, and likewise, but adding it to nouns to indicate in relation to is sloppy thinking and writing. Made-up words like politicswise, P.R.-wise, leadershipwise, policywise, datawise, and mediawise are unpleasant to the eye as well as to the ear."
} 
(2) Hopefully you \& B. have managed to get some resistance to the 'nursery germs' and will have a better winter cold \& flu-wise.

Whence, then, the sudden revival in the use of the suffix -wise in modern English, and what has caused a transformation of a hitherto (relatively) unproductive suffix into a productive one, following, implicitly, a semantic change?

\section{The development of the suffix -wise and its different meanings}

The origin of the suffix -wise can be traced back to the Old English noun meaning 'manner, fashion' and while the independent noun is no longer used in modern English, the nominal form has survived in some combinations and certain phrases, such as otherwise, in any wise, in no wise (cf. The Random House Unabridged Dictionary 1993: 2182). The suffixal use of -wise is of a later date; the suffix has been attached to nominal (also adjectival) bases to form either adverbs of manner (e.g., counterclockwise) or adverbs (and adjectives) denoting dimension or direction (e.g., lengthwise and its synonym lenghtways). The most recent addition has been the socalled 'viewpoint' form of -wise (cf. Dalton-Puffer and Plag 2000: 236; Yezbick and Closs Traugott 2005: 105), illustrated by example sentences (1) and (2) above, and probably first commented on by D.E. Houghton back in 1968. Houghton dated its appearance to the 1940s and observed that the use of the suffix -wise had gained wide currency in American English within a relatively short period of time, giving rise to a number of new coinages appearing particularly in the mass media and in spoken discourse (cf. Houghton 1968). While the two earlier uses ('manner' and 'dimension') of the suffix -wise were lexicalized by the mid-twentieth century (cf. Yezbick and Closs Traugott 2005: 105), and are therefore well documented in most English monolingual dictionaries, ${ }^{3}$ as well as regarded as practically unproductive by most authors (cf. Quirk et al. 1985: 1557, Dalton-Puffer and Plag 2000; Plag 2006, Cowie 2006), the 'viewpoint' use seems to be freely productive in modern speech and writing on both sides of the Atlantic. Any novel combinations ending in -wise appearing in the English language today therefore tend to be viewpoint adverbs.

It is this third meaning which is to be dealt with in the present article, since its productivity makes it an interesting topic to explore also from the non-native-speaker

\footnotetext{
${ }^{2}$ According to Lenker (2002; cited in Cowie 2006: 7), other terms used for such coinages ending in -wise are "viewpoint adverbials", "domain adverbials" and "sentence adverbials."

${ }^{3}$ The Random House Unabridged Dictionary (Flexner ed. 1993) lists thirty-seven instances of adverbs ending in -wise. Of these, several are old in the language, and most of these date from either the Old English or Middle English period (anywise, contrariwise, leastwise, nowise, otherwise, somewise). The majority of the adverbs listed, however, seem to denote either 'manner' or 'dimension' or both, and may have doublets ending in -ways (anticlockwise, breadthewise/breadthways, clockwise, coastwise, contraclockwise, cornerwise/cornerways, counterclockwise, crabwise, crosswise/crossways, edgewiseledgeways, endwise/endways, fanwise, flatwise/flatways, groupwise, lengthwise, longwise, manwise, pairwise, piecewise, saltirewise/saltireways, sidewise/sideways, slantwise/slantways, spokewise, stepwise, sunwise, termwise, warpwise, weftwise, widthwise/widthways). One adverb listed could be interpreted as a viewpoint adverb, namely dollarwise (Flexner ed. 1993: 580): adv.1. as expressed in dollars; in dollars and cents: How much does a million francs amount to, dollarwise? . 2. on a monetary basis; financially: The plan has disadvantages, but we will come out ahead dollarwise.
} 
perspective. The suffix -wise is in this case used to form non-gradable adverbs from nominal bases in the sense 'so far as [BASE] is concerned' (cf. Quirk et al. 1985: 1557) or, 'as regards [BASE]' (cf. Pullum and Huddleston 2002: 567), or, in other words, 'if we consider what we are saying from [BASE] point of view' (cf. Quirk et al. 1985: 568 and Dalton-Puffer and Plag 2000: 239).

It is interesting to note that both of the most influential grammars of the English language (Quirk et al. 1985 and the more recent Pullum and Huddleston 2002) claim that the use of the viewpoint -wise is more freely productive and more common in American English than in British English (cf. Quirk et al. 1985: 1557 and Pullum and Huddleston 2002: 567). While this was probably so in the 1980s when A Comprehensive Grammar of the English Language was published, this may no longer be the case today; judging from recent research on the British National Corpus (cf. Cowie 2006 and Dalton-Puffer and Plag 2000), British English does not seem to be lagging behind in the production of viewpoint -wise adverbs.

Grammatically, adverbs of this kind are used as domain adjuncts, ${ }^{4}$ restricting the domain to which the rest of the clause applies and typically appearing at the beginning of the sentence. In English, they can be paraphrased by several different prepositional phrases, e.g., as far as $X$ [noun] (is concerned), from a $X$ [adjective] point of view, from a $X$ [adjective] perspective, as regards $X$ [noun], regarding $X$ [noun], with respect to $X$ [noun], etc., the translational equivalents of which tend to be used in corresponding Slovene sentences to express similar or identical meanings. In order to illustrate the above point, the following example contexts have been selected taken from various Internet sources (all accessed on January 26, 2007): ${ }^{5}$

\section{weatherwise}

Weatherwise, there are a few seasonal variations which you might want to consider when planning your holiday. (www.gothailand.com/frameme.php?page=seas-choices.htm)

Still very sad here weatherwise; there have only been a couple of hot sunny days in the last month. (www.esatclear.ie/ emal/diary5.html)

\section{from the weather perspective}

From the weather perspective, mid-April to November is a good time to visit. (travel. nytimes.com/travel/guides /europe/denmark/when-to-go.html)

Saturday was a fascinating day from the weather perspective, the most incredible

\footnotetext{
${ }^{4}$ In Quirk et al. (1985: 568) these are referred to as viewpoint subjuncts. They perform the semantic role of viewpoint in that the base of the adverb acts as a relevant point of reference for the clause. In this semantic role, they also seem to share certain properties with disjuncts conveying the speaker's evaluation of the communicated content (cf. Lenker 2002: 163). However, they differ from disjuncts in that they are still "relatively integrated within the structure of the clause" (Quirk et al. 1985: 440).

${ }^{5}$ It should be noted, however, that not all adverbs ending in -wise and (seemingly) expressing viewpoint can be paraphrased in the ways suggested above (see, for example, illustrative sentences under (18) and (27) in Appendix I, in which the adverbs team-wise and club-wise would probably be more clearly paraphrased by using 'as a team' and 'in club competition' respectively). It is also important to bear in mind that the paraphrases may differ from the shorter -wise adverb in style, particularly in the level of formality.
} 
cloud formation moving in different direction. (www.oceanregatta.com/news/richard_wood.htm)

\section{As far as the weather (goes/is concerned)}

As far as the weather goes on this first day of 2007, we are continuing with mild conditions, and rain will continue as well. (www.courant.com/news/local/hc-weathercolsg,0,1417754.storygallery)

"We've had bad seasons in the past, but this is probably going to be the worst that I have seen, season-wise, as far as the weather is concerned." (industryreport.mountainnews.com/2006/12/eastern_resorts_suffering_euro.shtml)

\section{as regards the weather}

Autumn and spring are considerably unstable as regards the weather. Due to its proximity to the south pole and the variations of the January solstice, ... (www.enjoy-patagonia.org/ushuaia-when-to-go-weather-climate.php)

As regards the weather it doesn't look likely to be a very complicated passage. We'll pass north of the zone of the Azores High. (seasailsurf.com/seasailsurf/actu/spip. php?article3232)

\section{regarding the weather}

Besides the invariable calendar with detailed astronomical information and hazardous guesses regarding the weather, there was a list of the principal roads, ... (links.jstor.org/sici?sici=0161-91X(193206)19\%3A1\%3C3\%3AACCTTO\%3E2.0.C $\mathrm{O} \% 3 \mathrm{~B} 2-\mathrm{G}-)$

And regarding the weather, there's a notice on www.ouhsc.edu/insideHSC saying that campus will be open tomorrow. (forums.studentdoctor.net/showthread. php? $\mathrm{p}=4626599$ )

\section{with respect to the weather}

With respect to the weather this week, unseasonably dry weather covered most of southern Africa during the past week, with little or no rain falling from ... (www. fews.net/weather/index.aspx?pageID=weatherDoc\&g=1000183)

With respect to the weather in Africa, the remains of Cyclone Delfina continued to bring heavy rains and the potential for flooding to ... (www.fews.net/Weather/index. aspx?pageID=weatherDoc\&g=1000208)

Apart from the above paraphrases, some semantic overlapping can also be observed between adverbial constructions formed from adjectives and the suffix -ly and used as (domain) subjuncts, and the viewpoint -wise adverbs. Both constructions can be used to restrict the topic of the clause by narrowing down its perspective. However, there seems to remain an important difference in the level of formality between these, semantically quite equivalent sentences: ${ }^{6}$

(3) Financially, he'd be no worse off; and, anyway, he'd given County his word.

(4) Money wise he'd be way out of our price range and kill our salary cap.

${ }^{6}$ Sentences (3) and (4) have been quoted from the following Internet sources: orange. football365.com/Story/0,17169,8750_2172293,00.html mvn.com/nfl-giants/?comments_popup=1170 A similar meaning can be found in context no. (6) in Appendix I. 
While the formation of such -ly forms is restricted to adjectival bases of Latin origin with the -(ic)al ending, the suffix -wise seems freely combinable with any nominal base.

Most adverbs in -wise tend to be written without hyphens as single words, unless they are nonce words (or hapaxes ${ }^{7}$ in corpus terminology). The use of the hyphen suggests some degree of "uneasiness" on the part of the author of the text about using the adverbial form in -wise instead of the (albeit longer) prepositional (para)phrase (cf. also Quirk et al. 1985: 569). Huddleston and Pullum (2002: 567) also comment that this more recent use of -wise yields "numerous nonce-forms, largely restricted to informal style." In 1968 Houghton observed that the new coinages in -wise appeared mainly in the mass media and in spoken discourse (Houghton 1968: 211, 212), with Plag et al. (1999: 220) proffering a similar opinion thirty years on, claiming that -wise is "significantly more widely used in context-governed speech than in written language." However, Cowie's research of the BNC seems to suggest that viewpoint -wise is not straightforwardly characteristic of spoken interaction, and that certain types of written texts also tend to produce -wise viewpoint adverbs (cf. Cowie 2006: 6). Although her analysis of the BNC supports "a specialist, professionally-based, spoken register of origin" for the -wise viewpoint adverbs, the written sub-corpus shows accumulation of -wise viewpoint adverbs in the domains of arts, leisure and world affairs, particularly in the genre of popular magazines aimed at special interest groups (cf. Cowie 2006: 23). Typically, -wise viewpoint adverbs can be found in non-academic, (popular-)scientific texts, usually written for specialized audiences (cf. Cowie 2006: 24-25). Similarly, Yezbick and Closs Traugott (2005: 107-108) argue that -wise viewpoint adverbs have become quite frequent in texts found on the Internet, particularly in pages characterized by computer-mediated "youthspeak." When comparing the domains of the contexts from The Guardian Unlimited (accessed in January 2007) in Appendix I, one notices that several have appeared in the sports pages of the newspapers (no. 5, 6, 13, 17, 18, 25, 26, 27), while the others can mainly be found in sections dedicated to leisure, culture and arts, but typically in texts written with a personal tone, such as reviews, comments and analyses. None could be found in texts dealing with politics (international and UK news), finance, science and technology.

This brings us to another tendency characteristic of written texts in which -wise viewpoint adverbs occur. Most of these texts display similarities to spoken discourse; a personal letter to a friend may be said to "imitate" a chat, reviews and tests found in specialist hobby magazines resemble conversations held between members of a community (cf. also Cowie 2006: 26). A closer look at the twenty-five illustrative examples containing -wise viewpoint adverbs selected from The Guardian Unlimited (accessed in January 2007; cf. Appendix I) seems to confirm this typical feature. The majority of them occur in clauses which are actually represented spoken discourse, i.e., in citations, reported speech and free indirect discourse, e.g., examples no. 5, 6, $7,12,13,18,19,21,22,23,25,27,28,29$. Several are imitative of "shop-talk" (e.g.,

\footnotetext{
${ }^{7}$ In corpus linguistics, hapaxes are regarded as the best indicators of productivity as they are most likely to represent words that are actually novel in the language (cf. Baayen and Renouf 1996: 74).
} 
test of coffee makers under no. 9, also numbers 10 and 24) and quite a few are very personal and involved in style, which again brings them close in structure to conversation $^{8}$ (e.g., a My Week diary column under no. 20, also numbers 11, 14 and 16).

\section{Treatment of the productive suffix -wise by English lexicography and word- formation}

When non-native speakers of English are confronted with an unfamiliar word such as a -wise viewpoint adverb, they would, probably, try to consult a dictionary to clarify the meaning of this unknown word. Unfortunately, since most formations with the suffix -wise are nonce-forms, coined by authors for a particular text, dictionaries do not include them. However, dictionary users might consider checking the meaning of the suffix itself, which, combined with the meaning of the base, should give them a fairly precise idea of the meaning of a new coinage.

Most modern dictionaries of the English language cover the viewpoint meaning of the suffix -wise. To take an example of a monolingual unabridged dictionary, the Random House Unabridged Dictionary (Flexner ed. 1993: 2182) lists -wise as a suffixal use of the noun ' wise $^{2}$ ' in adverbs denoting manner, position, direction, reference, etc., and cites as examples counterclockwise; edgewise; marketwise; timewise. It also includes a usage note, saying that "the suffix -wise is old in the language in adverbs referring to manner, direction, etc.: crosswise; lengthwise. Coinages like marketwise, saleswise, and weatherwise are often criticized, perhaps because of their association with the media." Added to this is an illustrative example (Otherwise - or moneywise, as they were already saying in the motion-picture industry - Hollywood was at the crest of its supercolossal glory.), which, however, can be felt to be lacking in clarity as to the viewpoint -wise usage since it may confuse the reader into believing that otherwise and moneywise can be regarded as synonymic alternatives due to their positioning next to the conjunction or. Another important piece of information is given: "This suffix should not be confused with the adjective wise ${ }^{1}$, which appears in such compound words as streetwise and worldly-wise."

The viewpoint -wise suffix is also covered by EFL dictionaries. When comparing the treatment of -wise in two recent ones, the Macmillan English Dictionary for Advanced Learners (Mayor ed. 2002) and the Collins Cobuild English Dictionary for Advanced Learners (Sinclair ed. 2001), one notices that the former lists both the viewpoint meaning and the directional meaning, while the latter lists the viewpoint meaning along with the (probably wider) manner meaning:

-wise 1 speaking of or referring to: used with many nouns, verbs and adjectives: It was a poor show, talent-wise (=speaking of talent). weather-wise (=referring to the weather) 2 in the direction of: used with some nouns and adjectives: lengthwise (=from one end to another) cross-wise (=in a cross direction) (Macmillan English Dictionary for Advanced Learners, Mayor ed. 2002: 1648)

1 -wise is added to nouns to form adverbs indicating that something is the case when considering the particular thing mentioned. $\square$ Career-wise, this illness

\footnotetext{
${ }^{8}$ Cowie (2006: 21) labels this kind of text "personal testimony."
} 
couldn't have come at a worse time... It was a much better day weather-wise... Because the work was voluntary it was flexible, time-wise.

2 -wise is added to nouns to form adverbs indicating that someone behaves in the same way as the person or thing that is mentioned. $\square$ We were housed student-wise in dormitory rooms... Kenny, struggling with too many chairs, moved crabwise towards the door.

(Collins Cobuild English Dictionary for Advanced Learners, Sinclair ed. 2001: 1796)

While the Macmillan English Dictionary allows the viewpoint -wise suffix to be added to nouns, adjectives and even verbs, the Collins Cobuild English Dictionary mentions only derivation from nouns. The illustrative sentences from Appendix I show that the overwhelming majority of the -wise viewpoint adverbs are derived from singular nouns, instances listed under numbers 8 and 21 from plural nouns, and instances under numbers 17 and 19 from -ing verbal noun forms. A feature shared by both dictionaries is that the material used in their compilation has been taken from extensive corpora of English texts, and, interestingly, neither of the two dictionaries advises against the use of -wise or labels it as informal, spoken, etc. Can this mean that the corpus material does not yield sufficient evidence as to the markedness of viewpoint -wise adverbs? Could the user infer from the information provided that the viewpoint -wise adverbial formation has indeed caught on in modern English?

Naturally, the viewpoint meaning of the suffix -wise is also treated by textbooks and reference literature dealing with English word-formation (cf., for example, the concise and informative paragraphs on -wise by Adams 2001: 39 or Plag 2003: 98). However, consulting a linguistic textbook tends not to be one's first-choice course of action when faced with a novel lexical item in a text. Also, the treatment of the viewpoint suffix -wise in the relevant literature on word-formation may not always be satisfactory (see also Dalton-Puffer and Plag 2000: 225). Interestingly and somewhat surprisingly, Bauer and Huddleston (in Huddleston and Pullum 2002: 1621-1721) do not comment on adverbialisation at all in their treatment of affixation in the chapter on lexical word-formation. Quirk et al. (1985: 1557), however, list the suffix -wise along with -ly and -ward(s) as one of the adverbial suffixes in their Appendix I on word-formation. The compact Collins Cobuild English Guides 2: Word Formation (Sinclair ed. 1991: 183-184), like the Collins Cobuild English Dictionary corpusbased, describes two productive uses of the -wise suffix, 'similarity' and 'with regard to something'. Unlike the dictionary, however, the guide comments on the informality and nonstandardness of some of the -wise formations with the viewpoint meaning.

\section{English-Slovene contrastive views on the productive suffix -wise}

In order to check the extent to which advanced non-native speakers of English can cope with the comprehension of hitherto unfamiliar -wise viewpoint adverbs, a group of fifty 3rd- and 4th-year university students of English at the Faculty of Arts in Ljubljana were asked to read the contexts listed in Appendix I and translate them into Slovene. As they were decoding into their mother tongue, they did not consult dictionaries in the process of translation and the viewpoint meaning of the -wise adverb was not explained to them beforehand. 
Overall, the understanding of the -wise combinations seemed relatively unproblematic, and the majority of the students' translations were accurate unless the context was entirely misinterpreted by a student due to lack of general knowledge or unfamiliarity with the topic itself (e.g., specific sports contexts). However, since the Slovene language does not possess an equivalent suffix to convey the same 'viewpoint' meaning, the students had to use a paraphrase in their translation or adopt some other strategy to interpret the meaning of the English context. Some of the more interesting strategies are to be analysed in the following paragraphs.

The sentence "Confidence-wise she definitely had the edge." in context no. (5) was slightly problematic as the phrase have the edge means 'have an advantage', which was not understood by some of the students tested. However, the translation of the coinage confidence-wise did not seem problematic. Over one half of the students $(60 \%)$ opted for one of the accurate Slovene paraphrases, by far the most frequent being kar se tiče samozavesti/zaupanja (vase) ( 24 out of 50; 48\%), followed by glede samozaupanja/samozavesti; glede na samozavest (4 out of $50 ; 8 \%$ ) and $z$ vidikal stališč samozavesti ( 2 out of 50; 4\%). In most other translations (28\%), none of the -wise equivalent paraphrases were used, but the overall meaning of the sentence was nevertheless not distorted: ${ }^{9}$

S svojo samozavestjo je bila gotovo v prednosti. 'Her confidence definitely gave her the advantage.'

Samozavesti ji zagotovo ni manjkalo. 'She certainly did not lack confidence.'

Ona je bila bolj samozavestna. 'She was the more confident player.'

Zagotovo je bila bolj samozavestna/samozavestnejša od mene. 'She was certainly more confident than I was.'

Another suitable translation was the causative one:

Zaradi svoje samozavesti je bila zagotovo $v$ prednosti. 'Because of her confidence she certainly had an advantage.'

And another translation which probably still gives the gist of the original text was:

Bila je zelo prepričana vase. 'She was very sure of herself.'

It seems that the reasons for any misinterpretation, and, consequently, inaccurate translation of the sentence in context no. (5) lie in the fact that the students have failed to interpret the noun edge in the meaning of 'advantage' ( 6 out of 50 or 12\%). Hence the following solutions:

Po samozavesti sodeč je zagotovo imela vse možnosti. 'Judging by her confidence, she certainly had all the possibilities (to win).'

$S$ samozavestjo je bila definitivno na robu. 'With her confidence she was on the brink/verge (of despair).'

Kar je čisto razumno, saj je definitivno na robu kariere. 'This is quite understandable, as she has reached the end of her career.'

Č povem po resnici, definitivno je imela prav. 'To tell the truth, she was certainly right.'

\footnotetext{
${ }^{9}$ Approximate English translations are given in single quotes.
} 
$Z$ zaupanjem vase je zagotovo imela svojo ostrino. 'Her confidence certainly gave her sharpness.'

Samozavestna kot je, je definitivno imela možnosti za zmago. 'Confident as she is, she certainly had chances to win.'

The sentence "Music wise I find Radio 2 more exciting" in context no. (12) was properly understood and therefore accurately translated by most of the students (94\%). The paraphrases used in translations contained either kar se tiče (same) glasbe (20 out of 50 or $40 \%$ ) or glede glasbe / glede na glasbo (11 out of 50 or $22 \%$ ); some students opted for $z$ vidika glasbe / z glasbenega vidika or po glasbi sodeč or kar zadeva samo glasbo (4 out of 50 or $8 \%$ ). About a quarter of the students (12 out of 50 or $24 \%$ ) chose to convey the meaning of the English sentence without employing one of the equivalent Slovene paraphrases:

Radio 2 (pa) vrti (veliko) boljšo glasbo. 'Radio 2 (, however,) plays (much) better music.'

Glasba, ki jo predvaja Radio 2, me veliko bolj navdušuje. 'The music played by Radio 2 gives me more pleasure.'

Glasba na Radiu 2 se mi zdi boljša. 'I think the music played on Radio 2 is better.'

Glasba mi je na Radiu 2 bolj všeč. 'The music on Radio 2 is more to my liking.'

Glasbeni program na Radiu 2 se mi zdi bolj pester. 'I find Radio 2's music programme more varied.'

Po izbiri glasbe mi je Radio 2 bolj všeč. 'The choice of music on Radio 2 is more to my liking.'

Ko pa govorimo o izbiri glasbe, mi je Radio 2 veliko bolj všeč. 'When talking about the choice of music, I like Radio 2 better.'

Po mojem mnenju na Radiu 2 vrtijo boljšo glasbo. 'In my opinion Radio 2 plays better music.'

Radio 2 predvaja bolj zanimivo glasbo. 'Radio 2 plays more interesting music.'

Glasbeno mi je bolj všeč Radio 2. 'Musically, I like Radio 2 better.'

Glasba na Radiu 2 se mi zdi zelo dobra. 'I find the music on Radio 2 very good.'

Three of the students $(6 \%)$ misinterpreted the meaning of the original English sentence and produced the following translations:

Podobno kot glasba se mi zdi Radio 2 bolj zanimiv. 'I find Radio 2, like its music, more interesting.'

Podkovana na področju glasbe lahko rečem, da se mi zdi Radio 2 bolj vznemirljiv. 'Well acquainted with the field of music I can say that I find Radio 2 more exciting.'

Ker se spoznam na glasbo, se mi zdi Radio 2 bolj vznemirljiv. 'Being an expert in music, I find Radio 2 more exciting.'

In the translation of the sentence "I don't think we've ever played as well teamwise as we have during this series" in context no. (18), the students chose a number of diverse formulations in Slovene. The most frequent strategy employed was to translate team-wise with an equivalent consisting of as + noun (in Slovene: kot 
ekipa/moštvo/tim/skupina 'as a team') combined with the verb (24 out of 50; 48\%). Another frequent choice was to use an adverb such as ekipno, skupinsko, timsko, moštveno, or kolektivno, as well as usklajeno or povezano, to qualify the verb igrati 'play' ( 14 out of 50 or $28 \%$ ). Only rarely were the translations in which the equivalent paraphrases were used: kar se moštvene/timske igre tiče; kar se tiče enotnosti ekipe; s stališča timske igre appeared in only 4 out of 50 translations (8\%). Similar were the following paraphrases ( 3 out of $50 ; 6 \%$ ):

Mislim, da v ekipnem smislu še nikoli nismo igrali tako dobro kot $v$ tej ligi. 'I think that we've never played so well in the team-sense.'

Mislim, da še nikoli nismo igrali v tako timskem/ekipnem duhu, kot smo v zadnjih igrah. 'I think we'd never played in such team spirit as we have during this series.'

In one of the translations (2\%), the meaning of the adverb team-wise was expressed adjectivally:

Zdi se mi, da naša igra še nikdar ni bila tako moštvena kot med to tekmo. 'I feel that our play has never been so team(-oriented) as during this series.'

In several other translations ( 3 out of 50 or $6 \%$ ), the students chose some other strategy without having distorted the meaning of the overall sentence:

Menim, da še nikoli nismo prikazali tako dobrega sodelovanja znotraj ekipe kot $v$ tej seriji. 'I don't think we've ever shown such good cooperation within the team as in this series.'

Ne vem, če je bil v naši ekipi že kdaj prisoten takšen skupinski duh, kot nas je preveval to sezono. 'I don't think our team has ever shown such community spirit as during this series.'

Mislim, da ekipa še nikoli ni delovala bolje kot to sezono. 'I think the team has never acted so well as during this series.'

One translation (2\%) was left incomplete and is inaccurate:

Mislim, da nikoli do zdaj nismo igrali bolj tako ... kot tim. 'I think we've never played more ... as a team.'

The sentence "Students have put a lot into the last three years, family and job wise, to qualify" from context no. (29) proved to be a difficult one to understand and, consequently, translate accurately. Half of the students (50\%) misunderstood and misinterpreted the context, in most of these cases the meaning conveyed in translation was that students have invested a great deal into their jobs and families in order to qualify, which, considering the entire context and the title of the article, makes little sense. In 17 cases, the translations yielded by the students were correct (34\%), yet in only three of these $(6 \%)$, the translators used one of the equivalent Slovene paraphrases normally associated with the viewpoint -wise adverb, with glede družine in službe appearing twice in the translations:

Študentje so vložili veliko truda in odrekanj v zadnja tri leta, vsaj kar zadeva družino in službo, da bi se kvalificirali.

Študenti so v preteklih treh letih vložili v to veliko napora, tako glede družine kot službe... 
All the other accurate translations (14 out of 50 or $28 \%$ ) were freer and the students employed various strategies to convey the meaning of the -wise adverb:

Študenti so se v zadnjih treh letih odrekli veliko stvarem - (recimo) službi, družini - da bi se kvalificirali. 'In the last three years, students have sacrificed many things, (such as) jobs and families, to qualify.'

Študentje so $v$ zadnjih treh letih, da bi se lahko kvalificirali, izkusili mnogo odrekanja $v$ družini in na delovnem mestu. 'During the last three years, in order to qualify, students have experienced much sacrifice both in their families and jobs.'

Študentje so za kvalifikacijo žrtvovali veliko, tudi družino in delo. 'Students have made many sacrifices for their qualifications, even families and jobs.'

Študenti so vložili veliko truda, da bi se kvalificirali. Po strani so pustili tudi družino in posel. 'Students have made an effort to qualify, sacrificing their families and jobs.'

Študenti so se zadnja tri leta zelo trudili, da bi dosegli izobrazbo, in se marsičesa odrekali, tako na družinskem kot profesionalnem področju. 'Students have tried very hard for the last three years to get their qualification, and have given up many things, both in the area of family and job.'

Študenti so vložili veliko v zadnja tri leta, kar je vplivalo na njihovo družino in službo... 'Students have put a lot into the last three years, which has affected their families and jobs...'

Several translations, however, could be described as ambiguous (8 out of 50 or $16 \%$ ) as they do not explicitly specify that families and jobs were neglected because students have invested so much time and energy in their studies. Here are two example translations of this kind:

Študenti so, kar se tiče družine in službe, vložili veliko v zadnja tri leta, da bi se kvalificirali/uvrstili. 'Students have, as far as family and job are concerned, put a lot into the last three years to qualify.'

Študenti so veliko vložili v zadnja tri leta, da bi se kvalificirali; gledano tako s strani družine kot službe. 'Students have put a lot into the last three years to qualify, seen both from the aspect of the family and job.'

\section{Conclusion}

Judging from the above findings, we may conclude that adverbial -wise coinages do not present a major problem in the comprehension of English texts for advanced learners of English. In most cases, the context helps them to interpret the coinage correctly, unless they are unfamiliar with the topic itself. When translating such contexts into Slovene, which does not possess an equivalent suffix to convey the same 'viewpoint' meaning, one either has to use a paraphrase in translation or adopt some other strategy to interpret the meaning of the English context.

It seems that the clause-initial position of the -wise adverb prompts a translation which tends to include one of the possible paraphrases (e.g., kar se tiče $+\mathrm{N}$; kar zadeva $+\mathrm{N}$; glede $(n a)+\mathrm{N} ; z$ vidika/stališča $+\mathrm{N} ; p o+\mathrm{N}+$ sodeč), while non-initial positions of the -wise adverbs tend to yield freer translations, but further research is 
needed here to provide more evidence to either support or rule out this assumption. However, the choice of a translation strategy also depends on the organization of the text itself and on the translator's awareness of the most natural and idiomatic way of expressing a certain content in the target language. Thus, it is not surprising that team-wise was most frequently translated into Slovene by employing an equivalent of as a team, because this is the formulation most often encountered in Slovene texts dealing with similar topics.

\section{Appendix I}

Illustrative examples containing -wise viewpoint adverbs (underlined) taken from The Guardian Unlimited (http://www.guardian.co.uk/)

(5) "I had the best chances today to beat her from all the matches we've played in the past," she said. "Confidence-wise she definitely had the edge. But this time I definitely stepped it up. In the beginning we both were very nervous. But I came out stronger and I had my chances today. It was definitely disappointing. I felt like I was winning the match and I had all the things in my hands. But she's a great fighter. It was a great match." ("Sharapova and Clijsters Struggle Through." Guardian Unlimited, Wednesday January 24, 2007)

(6) It has been a difficult week for Redknapp with Lomana LuaLua and Glen Johnson appearing in the news for the wrong reasons and Campbell enduring a scare in a difficult landing on a flight back from Paris. The upside was the capture of Lauren from Arsenal, a player he was "very surprised" to sign - "he'd have been better off [wagewise] at West Ham, much better off, but he decided to come to us." ("Pardew Takes Heart from Redknapp's Survival Guide." Guardian, Monday January 22, 2007)

(7) Gregory says that to keep their sanity, they took things one day at a time and believed that at the end of the project the new Wembley would be an amazing stadium. "It would have been harder if we'd known how long it would take to sort out the issues," Gregory admits.

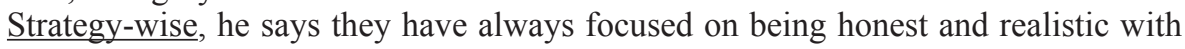
the messages going out, be they to fans, the media or the Club Wembley seat-holders, who had paid up with the expectation of being at the first cup final at the stadium. (“Mission Impossible?" Guardian, Monday January 22, 2007)

(8) Start from London, to experience the full force: you cross the incredibly windy bridge over the Medway. There is a train bridge adjacent. Race the train! The countryside of Rochester unwraps itself before you like the credit sequence of a pastoral sitcom about vets. Slow down if you will, to wait for a big gust of wind, then put your foot down as you veer wildly from one lane to another. It's like a video game, particularly if you are a bad driver and have a very old automatic car whose handling isn't great at the best of times.

Services-wise, there ain't much meat on her, but what there is is choice, as Spencer Tracey used to say of Katharine Hepburn, in his not-at-all-demeaning account of their life-long love affair. Medway is a Moto. Its loos are very clean, on account of the rigorous, no-nonsense natures of the people of Thanet. To my knowledge, it has never run out of the key sections of pick-and-mix, unlike some services I could 
mention, which run out of white mice almost immediately, but don't actually bother replacing any until they're down to their last chocolate brazil. It was among the first motorway service stations to start proselytising about fruit portions, over the distracting olfactory hum of frying bacon. It's interesting that, while Burger Kings are the same the country over, there is variation within the genre "Upper Crust", and I think this one is among the classiest. It's something to do with not always thinking that everyone wants the brie and bacon, and sometimes mixing it up a bit with a coronation chicken. I have never been scammed by a broken quiz machine, nor found anything in a soup that wasn't part of the description, nor been cheeked by the Saturday staff. I really can't fault any part of the M2 experience. ("Life in the Fast Lane-Part Two." Guardian Unlimited, Monday January 22, 2007)

(9) The Cuisinart Grind and Brew guarantees perfect results every time. The only coffee machine on the market that can grind fresh coffee beans and is fully automatic. $[\ldots]$

If you're after a continuous filter machine, then this could be good. It is simple to use and makes that perfect, American-style coffee. This grinds beans, which is a really good feature, since it means you won't lose flavour and the beans will stay fresh. It is very sturdy but style-wise, the brushed stainless-steel finish would raise maintenance issues - it positively attracts filth and fingerprints. ("Five on Test: Coffee-Makers." Observer, Sunday January 21, 2007)

(10) Like the town in which it resides, La Zouch's menu is a steady mix of English and Continental. Its current table d'hote menu offers the likes of braised lamb shanks or chicken fillets in a wine and cream sauce - all for a bargain price. But it's the restaurant's other face as a specialist drinks outlet which really put it on the map. After diversifying his operation in the face of the early 1990s recession, co-owner Geoff Utting has built up one of the Midlands' most comprehensive whisky selections. He currently stocks in excess of 300 single malts plus a range of blends, Irish whiskies and bourbons plus speciality vodkas, cognacs and wines. Whisky-wise, La Zouch has a particular focus on the five distilleries of Tobermory, Glengoyne, Isle of Arran, Bruichladdich and Benromach where there's a good stab at stocking every expression. The restaurant offers an outstanding drinks range while the separate private dining rooms host a number of wine and whisky tastings throughout the year. ("Preview." Guardian, Saturday January 20, 2007)

(11) Last year, I was 39, and a size 22. This is seriously big - huge, actually. Hippopotamoid. If you're short, you look like a ball of dough, with two titchy currants for eyes; if you're tall-I'm $5 \mathrm{ft} 10$ - you look like a wrestler, or a drag queen gone to seed. This year, I'm 40 and I am a size 14 on top (unshiftable bosoms, the boredom) and a 12 below. I've lost five stone. I am unbelievably pleased with myself, though of course it's quite odd that a size 14 should strike me as the acme of perfection, sizewise, and strike other women as being about an inch away from monstrous heiferdom. But I can live with that. The reason I got so fat - well, one of them-in the first place is that I had, and continue to have, an absolute horror of those women who push a leaf around a plate and call it lunch, or who 'forget' to eat (yeah, right) or-worst of all — who use inappropriate adjectives to describe food. Deliberately tripping up 
someone is 'naughty'; stabbing your boyfriend in the head for a laugh is 'sinful'. Chocolate cake is neither. ("Fat Girl Thin." Observer, Sunday January 14, 2007)

(12) Asked if she had any ambitions to work at Radio 1, Laverne said: "I am very happy at Xfm, but I am open to offers. I am a fan of [Radio 1's] Edith Bowman.

"Music wise I find Radio 2 more exciting. Maybe that is because it's a point of difference because I work at Xfm."

Laverne said Radio 1 had its "strengths and weaknesses. I prefer to listen to their specialist shows. They are some of the most exciting specialist shows on radio." ("Laverne Slams 'Sexist' Radio Industry." Guardian Unlimited, Friday January 12, 2007)

(13) "Alec Stewart played until he was 40 and I would like to think that, fitness wise, I am up there with him. I've just turned 36, I'm as fit as anyone in the game and I still love it. I'd be a liar if I didn't say that the World Cup was at the back of my mind. You never think your England chance has gone because all you ever work for is the chance to represent your country. I am passionate about the game and about doing well and winning. Duncan Fletcher aims high and hopefully I can keep learning. Realistically, being behind Stewart at his peak, I knew I was never going to play. It's different this time around. Hopefully a calm head and experience will help." "'Old Rival Shows Nixon that if You're Fit Enough You're Young Enough." Guardian, Tuesday January $9,2007)$

(14) Is it really true that the British still suffer from emotional constipation, or is it just a hoary old quasi-xenophobic chestnut? Confusion may stem from the fact that, gender-wise, we get upset 'differently'. British men get emotional about silly, inconsequential things (Freddie Flintoff being bowled out, iPod malfunctions), while women cry about really important stuff (life, death, James McAvoy already being married). There is further confusion because men rarely see themselves as 'upset' (too girly); they call it being 'angry'. The whole thing is further muddled by the fact that British men are only commended for weeping publicly if it's about sport (Gazza at the 1990 World Cup; Matthew Pinsent with his rowing Olympic Gold). Any other male weeping (Les Dennis on Celebrity Big Brother) and you're damned forever as a Big Girl's Blouse. ("Stiff Upper Lip?" Observer, Sunday January 7, 2007)

(15) Obviously airshows are terrible sources of pollution, noise-wise and carbonwise, but most children are gripped by the sight, sound and smell of roaring jets, hovering helicopters and bombing biplanes. Best of all, with a bit of planning there's always a handy spot near the airfield where you can watch all the fun without a) paying for admission, and b) getting caught in the usually horrendous traffic jams. Some shows are free anyway, such as the Sunderland International Airshow, July 28-29, which is said to be the largest free airshow in Europe. If planes are beyond the pale, how about watching the London to Brighton Veteran Car Run in November? ("Ten Cool Things to Do with Kids." Guardian, Saturday January 6, 2007)

(16) In fact, men do have an internal check list, too; but it's not "does she have enough positives?", it's "does she not have half a dozen too many negatives?" And the list, moreover, consists of things like: 1) Did I find her laughing over the bodies of a 
number of my immediate family, clutching a bloody knife? and 2) Has this happened on more than one occasion? Application-wise, it is, quite frankly, easier to be turned down by some of the new universities than it is to fall below the standards required by the average bloke. ("The Internal Check List." Guardian, Saturday January 6, 2007)

(17) The gaffer has told us as much. He's played in the biggest FA Cup games in the past, so any advice he can give us is vital. He's added so much to my game already, from playing little balls round corners, anticipating second balls, and little things, positioning-wise. You're bound to improve just listening to him. If we hadn't been playing so well, he might have fancied pulling on his shirt for this game himself. But we've got maximum points over Christmas so he's confident we can give a good account of ourselves. ("GGet Tight, Make Our Presence Felt and Don't Let Them Play."” Guardian, Saturday January 6, 2007)

(18) “I don't think we've ever played as well team-wise as we have during this series. It's been an amazing series for us. It's been a huge team effort." (“"It Cannot Get Any Better."" Guardian Unlimited, Friday January 5, 2007)

(19) But the middle market is set to be significantly tougher. HMV and Woolworths both issued profit warnings at the beginning of December, and Mr Ratner said their Christmas trading updates were likely to be bad. He said: "Debenhams has not had a brilliant time, and my gut feeling is that Blacks Leisure has had a lousy time trading-wise." ("2006: the Year of the Online Christmas." Guardian, Wednesday January 3, 2007)

(20) Having been asked to do this My Week diary, I seek guidance and ask The Observer for an example - maybe last year's column for the same period, because the festive week is, after all, an odd one in which nothing much really happens workwise. But how wrong I am. Stephen Daldry's dizzying account of last year has him jetsetting from opening to opening while trying to avoid the ever-growing pile of film scripts that threatens to entomb him. ("My Week: Peter Capaldi." Observer, Sunday December 31, 2006)

(21) Why it deserved better by Suzanne Baboneau, publisher: "Le Carré-esque thriller set around the bombing of 1988. Was the hero's son on board the plane? That's the simple question at the heart of the novel that keeps you turning the pages through all the twists and turns to the end. Perhaps it's the hardback format that didn't attract. We have a different A-format paperback next April which will hopefully tell a different story sales-wise." (“If only ..." Guardian, Saturday December 23, 2006)

(22) The Relate counsellor Paula Hall points out that there's another difference in the mother/daughter, father/son debate. "For mothers, it's more about envying their daughters on an aesthetic and flexibility level, body-wise; whereas for fathers, they envy their son's vitality. Being aware of the ageing process means they can envy their son's speed of reactions, and their general staying power, in sport as well as sex," she says. "This envy is often mixed with nostalgia. It becomes unhealthy when the fathers feel they are missing out." ("Like Father, Like Son." Guardian, Saturday December 23, 2006)

(23) I don't think Jeff gets on with the new mayor, Doug Isaacson, who's apparently a steely-eyed, shaven-headed Bush Republican. Isaacson's big idea is apparently to get 
all the shopkeepers in town to wear elf costumes as a means of generating increased tourist revenue. Jeff feels this is just window dressing and it's what's on the inside that counts, Christmas-wise. ("Bad Tidings." Guardian, Saturday December 23, 2006)

(24) When's the best time for Christmas dinner, health-wise? Midday or evening? Definitely midday. Any experienced GP will tell you that the busiest time of the year for strokes and heart attacks is the early hours of Boxing Day morning. That's because a late fatty meal, plenty of alcohol and total relaxation (if not a drunken stupor) afterwards conspire together in the average (...) ("Christmas Meal Times." Guardian, Saturday December 23, 2006)

(25) 25th over: Australia 96-1 (Hayden 48, Ponting 44) Another Monty over comes and goes in a blur. Sorry if that lacks analytical rigour-I have been up most of the night. And most of yesterday too, come to think of it. "What's really depressing is that, though we can match the Aussies pound-for-pound talent wise, they just have the extra know-how to still be outfoxing us," reckons Matt Delargy. "Plucky young upstart losing out to wily old sea dog. It hurts." ("Over-by-Over: Evening Session." Guardian Unlimited, Friday December 15, 2006)

(26) Weather-wise he might have chosen a better day to showcase his talents, but he still walked off with the man-of-the-match award, albeit against a side that had lost their previous nine matches in Europe and were never going to be strong enough. Wasps, after slipping up at Perpignan, are once again sitting pretty and will expect to repeat yesterday's result in Italy next Saturday. However, the one dark cloud is the improving Heineken form of Castres, their final pool opponents. ("Waldouck Prompts Wasps to Swarm Treviso Try-Line.” Guardian, Monday December 11, 2006)

(27) "The radical plan has to be that the coach gains total control over the players and the playing time," he said yesterday. "Below that comes the issue of the number of games we play internationally, the number of games we play club-wise, the number of competitions we enter. It is a crazy system. We want to get the top players down to playing around 28 games a year." ("Woodward Rips into Andrew and Baron over England Mess." Guardian, Monday December 11, 2006)

(28) "I was basically using my knowledge as a journalist from my time at Sky Sports and Sky News," he says "I understood the drive for ratings and which way they would want to steer shows. I won $£ 19,000$ betting every week that Chico would stay even if he was bottom two in X Factor. Cowell would never get rid of him. Publicity-wise he was dynamite - on the front cover of the tabloids every day." ("Reality Cheque." Guardian, Saturday December 9, 2006)

(29) Hannah Harwood, 22, a second-year nursing student at Nottingham University, says: "Students have put a lot into the last three years, family and job wise, to qualify. So many people are relying on the job at the end, and it is going to be very disappointing for them. ("All Trained Up and Nowhere to Go." Guardian, Tuesday December $5,2006)$ 


\section{References}

Aarts, Bas and April McMahon, eds. 2006. The Handbook of English Linguistics. Oxford: Blackwell.

Adams, Valerie. 2001. Complex Words in English. English Language Series. Harlow, Essex: Longman.

Baayen, Harald and Antoinette Renouf. 1996. "Chronicling The Times: Productive Lexical Innovations in an English Newspaper." Language 72: 69-96.

Bauer, Laurie and Rodney Huddleston. 2002. "Lexical Word-Formation." in Huddleston and Pullum, pp. 1621-1721.

Cowie, Claire. 2006. "Economical with the Truth: Register Categories and the Functions of -wise Viewpoint Adverbs in the British National Corpus." ICAME Journal; Computers in English Linguistics (30): 5-36. (http://icame.uib.no/ij30/)

Dalton-Puffer, Christiane and Ingo Plag. 2000. "Categorywise, Some CompoundType Morphemes Seem to be Rather Suffix-like: On the Status of -ful, -type, and -wise in Present Day English." Folia Linguistica 34: 225-244.

Flexner, Stuart B., ed. 1993. Random House Unabridged Dictionary. New York: Random House.

Houghton, Donald E. 1968. “The Suffix -wise.” American Speech 43: 209-215.

Huddleston, Rodney and Geoffrey K. Pullum. 2002. The Cambridge Grammar of the English Language. Cambridge: Cambridge University Press.

Lenker, Ursula. 2002. "Is it, Stylewise or Otherwise, Wise to use -wise? Domain adverbials and the history of English -wise. In Fanego, Lopez-Couso and PérezGuerra (eds.), English Historical Syntax and Morphology: Selected Papers from 11 ICEHL, Santiago de Compostela, 7-11 September, 2000, 157-180. Amsterdam: John Benjamins.

Mayor, Michael, ed. 2002. Macmillan English Dictionary for Advanced Learners. Oxford: Macmillan.

Plag, Ingo, Christiane Dalton-Puffer and Harald Baayen. 1999. "Morphological Productivity Across Speech and Writing." English Language and Linguistics 3: 209-228.

Plag, Ingo. 2003. Word-Formation in English. Cambridge Textbooks in Linguistics. Cambridge: Cambridge University Press.

Plag, Ingo. 2006. "Productivity." in Aarts and McMahon (eds.), pp. 537-556.

Quirk, Randolph, Sidney Greenbaum, Geoffrey Leech and Jan Svartvik. 1985. A Comprehensive Grammar of the English Language. Harlow, Essex: Longman.

Sinclair, John, ed. 1991. Collins Cobuild English Guides 2: Word Formation. London: HarperCollins.

Sinclair, John, ed. 2001. Collins Cobuild English Dictionary for Advanced Learners. Glasgow: HarperCollins.

Yezbick, Ka'ala and Elizabeth Closs Traugott. 2005. "Recent Developments in Viewpoint -wise." American Speech 80: 105-112.

Prispelo novembra 2007, sprejeto februarja 2008

Received November 2007, accepted February 2008 


\section{Angleška pripona -wise in njena produktivnost $\mathrm{z}$ vidika tujega govorca}

Članek osvetljuje produktivno rabo angleške pripone -wise, ki se v zadnjih desetletjih pogosto pojavlja $v$ manj formalnih govorjenih in pisanih angleških besedilih. Angleški prislovi s pripono -wise lahko izražajo različne pomene, večinoma 'način' (npr. clockwise) ali 'dimenzijo' oz. 'smer' (npr. lengthwise); v teh pomenih je -wise v sodobni angleščini praktično neproduktiven. Od štiridesetih let 20. stoletja dalje pa angleški govorci tvorijo tudi prislove $\mathrm{z}$-wise, ki izražajo 'stališče' - ta raba je produktivna, čeprav jo nekateri slovničarji odsvetujejo. Takšne prislove $\mathrm{z}$-wise je $\mathrm{v}$ angleščini možno parafrazirati z določenimi predložnimi zvezami, npr. as far as $X$ is concerned, as far as $X$ goes, as regards $X$, from the $X$ perspective, regarding $X$, with respect to $X$, ali $\mathrm{v}$ določenih primerih celo nadomestiti s prislovi na -ly (npr. moneywise in financially), vendar je pri tem navadno opaziti določeno slogovno razliko v stopnji formalnosti. Ker je velika večina angleških prislovov z -wise, ki izražajo stališče, tvorjenih na novo za potrebe določenega besedila, jih slovarji angleškega jezika seveda ne vključujejo in ne razlagajo. V slovarjih najdemo le že leksikalizirane prislove z -wise, ki izražajo 'način' ali 'dimenzijo/smer'. Ko tuji govorec angleščine naleti na tvorjenko $\mathrm{z}$-wise, ki izraža stališče, njenega pomena ne more preveriti $\mathrm{v}$ slovarju; v slovarju lahko poišče le pomen same pripone -wise, kar mu, skupaj s pomenom samostalniške podstave, na katero se -wise veže, pomaga razjasniti pomen celotne tvorjenke. Da bi preverili, v kolikšni meri slovenski govorci angleščine razumejo enkratne tvorjenke $\mathrm{z}$-wise, smo testirali 50 študentov angleškega jezika $\mathrm{v} 3$. in 4. letniku študija na Filozofski fakulteti v Ljubljani. Testne osebe so v slovenščino dekodirale sobesedila, zbrana v Prilogi I, v katerih so se pojavljale tvorjenke z -wise. Izkazalo se je, da je razumevanje tvorjenk $\mathrm{z}$-wise za slovenske govorce relativno neproblematično. Večinoma je sobesedilo študentom zadostovalo, da so prislov z -wise pravilno interpretirali, do odstopanj je prišlo le v primeru, če je bilo celotno sobesedilo za testno osebo zaradi nepoznavanja tematike nerazumljivo (npr. določena športna besedila). Pri zahtevnejšem prevajanju v slovenščino so se testne osebe večinoma zatekle v eno od parafraz oz. opisnih ustreznikov, saj slovenščina ne pozna enake možnosti besedotvorne izpeljave za izražanje tega pomena: $z$ vidika/stališča $X$, kar se tiče $X$, kar zadeva X, glede (na) X, po X sodeč. Občasno so uporabile tudi drugačne prevajalske strategije, pri čemer so večinoma upoštevale samo zgradbo besedila in potrebo po naravnem izražanju v slovenščini.

\section{English Suffix -Wise and its Productivity from the Non-Native Speaker Perspective}

The article aims to shed some light on the productive use of the English suffix -wise, which, during the last decades, has been increasingly used in less formal spoken and written texts. English adverbs ending in -wise can denote various meanings, mainly 'manner' (e.g., clockwise) and 'dimension' or 'direction' (e.g., lengthwise); in these meanings the suffix -wise is practically unproductive in modern-day English. Since the 1940s English speakers have also used -wise to form 'viewpoint' adverbs - although this use is productive, speakers are often discouraged from it. The view- 
point -wise adverbs can be paraphrased by different prepositional phrases, e.g., as far as $X$ is concerned, as far as $X$ goes, as regards $X$, from the $X$ perspective, regarding $X$, with respect to $X$, in certain cases even substituted for by adverbs ending in -ly (e.g., moneywise by financially); however, speakers need to observe a certain stylistic difference in the level of formality between these substitutes and the viewpoint -wise adverb. Since the majority of viewpoint -wise adverbs in English are nonce-forms, coined by authors for a particular text only, they are not listed in and explained by English dictionaries. Only the lexicalized adverbs in -wise denoting 'manner' or 'dimension/direction' are treated by dictionaries. Thus, when non-native speakers of English come across a viewpoint -wise coinage, they cannot check its meaning in a dictionary; they can, however, check the meaning of the suffix -wise, which, combined with the meaning of the nominal base, can help them decipher the meaning of the new coinage. In order to check the extent to which Slovene speakers of English can cope with the comprehension of nonce formations with the suffix -wise, fifty 3rd- and 4th-year university students of English at the Faculty of Arts in Ljubljana were asked to read the contexts listed in Appendix I and translate them into Slovene. It turned out that the understanding of the -wise combinations was relatively unproblematic for advanced Slovene speakers of English. In most cases the contexts enabled the test persons to interpret the -wise adverbs accurately, individual misinterpretations occurred only when the entire context was incomprehensible because of unfamiliarity with the topic itself (e.g., specific sports contexts). The translation of the viewpoint -wise combinations into Slovene is more demanding than mere comprehension - the students tested

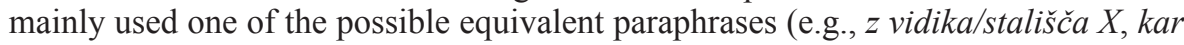
se tiče $X$, kar zadeva $X$, glede (na) X, po X sodec) as the Slovene language does not possess an equivalent suffix to convey the same 'viewpoint' meaning. Occasionally, however, some other translation strategies were used, depending on the organization of the text itself and the need for a natural and idiomatic expression in Slovene. 